\title{
Effect of Different Types of Mulching on Soil Properties and Tree Growth of Magnolia champaca Planted at the Montane Rainforest in Cameron Highlands, Pahang, Malaysia
}

\author{
Wahidullah Rahmani $\left(\mathbb{D},{ }^{1}\right.$ Mohd Nazre Salleh, ${ }^{1}$ Mohd Zaki Hamzah, ${ }^{2}$ Aminu Abdu, \\ Mohamad Fakhri Ishak, ${ }^{1}$ Wan Rasidah Wan Abd Khadir, ${ }^{3}$ Mohd Ridza Awang, ${ }^{3}$ \\ Zahari Ibrahim, ${ }^{3}$ Ahmad Fadzil Abd Majid, ${ }^{3}$ Mohd Shahrir Azrin Salleh, ${ }^{3}$ Azhar Anuar, ${ }^{2}$ \\ and Mohamad Azani Bin Alias $\mathbb{D}^{1}$ \\ ${ }^{1}$ Faculty of Forestry, Departement of Forestry Science and Biodiversity, Universiti Putra Malaysia, UPM Serdang 43400, \\ Selangor, Malaysia \\ ${ }^{2}$ Forest Research Institute Malaysia, Kuala Lumpur, Malaysia \\ ${ }^{3}$ Forestry Department of Peninsular Malaysia, Kuala Lumpur, Malaysia \\ Correspondence should be addressed to Mohamad Azani Bin Alias; azani@upm.edu.my
}

Received 3 February 2021; Revised 10 May 2021; Accepted 30 July 2021; Published 7 September 2021

Academic Editor: Qing Lai Dang

Copyright (c) 2021 Wahidullah Rahmani et al. This is an open access article distributed under the Creative Commons Attribution License, which permits unrestricted use, distribution, and reproduction in any medium, provided the original work is properly cited.

\begin{abstract}
Tropical Montane Cloud Forest (TMCF) is among the most vulnerable habitats to fragmentation, deforestation, and global climate change. A successful restoration program requires a comprehensive understanding of variables influencing seedling efficiency. This study was conducted on Sg. Terla Forest Reserve Cameron Highlands, Pahang, Malaysia. In this study, we used a randomized complete block design (RCBD) and measured the Magnolia champaca height, root collar diameter, diameter at breast height, plant survival, root diameter, main root length, lateral root length, root coiling, root direction, and chlorophyll content. The soil samples were taken to study the effect of different mulching materials on soil characteristics. We also measured soil compaction, soil texture, soil colour, soil moisture content, soil organic carbon, total nitrogen, total sulphur, available phosphorus, and exchanged potassium. This study indicates that mulching had no significant effect on plant height, diameter breast height, root collar diameter, and chlorophyll content between treatments. Although mulching had a significant effect on root diameter, main root length, and root distributions among treatments while for lateral root length and root:shoot ratio did not show a significant effect among treatments. However, oil palm mulching treatment had a greater effect on plant height, root collar diameter, and diameter at breast height growth, among treatments. Mulching significantly affected soil pH, soil moisture content, total sulphur, and potassium exchange. In contrast, mulching did not significantly affect soil organic carbon, total soil nitrogen, and soil available phosphorus between treatments.
\end{abstract}

\section{Introduction}

The protection of young plants from noncrop plant species is essential for the sustainability of new tree planting in both open-field nurseries and natural environments (including some hardwoods, shrubs, grasses, and forbs). These fastgrowing plants often eliminate or severely suppress desirable trees by competing for light, water, and nutrients. As a consequence, nurserymen, landscapers, and forest managers commonly use herbicides to manage noncrop vegetation [1] As a result, environmental friendly, secure, cost-effective, and socially appropriate methods for managing noncrop vegetation are needed to protect young trees [2]. In this circumstance, we concentrated on the need for environmentally sustainable establishment and low-cost restoration area management techniques. Mulching and its skilled 
application can lead to such development by increasing organic matter content in soils and influencing other soil characteristics [3]. Mulches have been commonly used in forests, agricultural land, orchards, and landscapes in many parts of the world $[4,5]$. Mulches are widely divided into three important groups: organic, inorganic, and living mulches. Green mulches are obtained from organic products such as crop waste (straw and rice husks), waste from the timber industry (sawdust and bark), and green waste (leaves and wood chips) [4]. Inorganic mulches involve gravel, film, bricks, and cobblestones made of polyethylene. Clover, Manila grass, dwarf lily turf, ryegrass, and other kinds of grasses include living mulches [6]. Each category of mulch has a particular set of characteristics. In general, mulches have beneficial effects such as improved early growth of trees, seed germination, increased root growth, higher water availability, maintaining good soil structure and porosity, minimizing soil erosion, reducing weed competition, maintaining soil temperature, reducing soil evaporation, enhanced root establishment and transplant survival, and increased overall plant performance $[7,8]$. Mulching has been shown to improve survival in nursery and field production [9], Silvopasture systems [10], woodland plantations [11], and restoration sites [12]. Researchers discovered that mulched trees grew $67 \%$ faster than bare soil trees as early as 1942 [13]. Many others have since shown similar increases in tree, shrub, and other plant material development in field and nursery conditions $[11,14,15]$. Specifically, increases in plant height $[1,10]$, stem or trunk diameter [16], leaf size and/or number [17], and flower, fruit, and/or seed production [18] have all been reported because of mulching with appropriate materials.

Various studies have shown that increased root growth and exploration by desirable plants is associated with better water retention and reduced weed growth [19]. As compared to bare soil [20], mulches allow tree and shrub roots to extend and establish far beyond the trunk, leading them to become more stable. Root development and density were greatest under organic mulches compared to that under plastic [19], bare soil, or living mulches. Mulches protect soils from extreme temperatures through maintaining soils cooler in hot conditions [21]. Temperature extremes will kill fine roots and while rarely killing established plantings, they can induce a chronic stress as the plant utilizes energy to generate new fine roots. Mulch protects soils from erosion and compaction caused by water, wind, and traffic, all of which contribute to root stress and poor plant health. Bare soil loses water by evaporation when exposed to wind, sun, and compacting forces and is less able to absorb rainfall or irrigation as it becomes rapidly compact. As compared to bare soil, a layer of straw only $3.8 \mathrm{~cm}$ (1.5 inch) thick reduced evaporation by about $35 \%$, according to an early study [20]. Later, McMillen [22] demonstrated that most mulched soils have greater water retention than bare soil. In general, inorganic and organic mulches are most effective in weed control when applied at sufficient depth and are least susceptible to compaction [14]. Living and organic mulches decompose under appropriate water and temperature levels and nutrients are released into the soil and become available for root uptake or microbial use. However, few studies have examined the impact of mulching in the restoration area under tropical climates. The study objectives were (1) to determine the effects of three types of mulches (organic, inorganic, and living) on soil properties and (2) to recognize the effects on the growth performance and (3) root development of Magnolia champaca in tropical montane rainforests, and to provide a preliminary recommendation for the selection of acceptable mulches based on our research.

\section{Materials and Methods}

2.1. Study Site. The present study was conducted in a former agriculture area located in the montane rainforest at Terla Forest Reserve Cameron Highlands (Figure 1). It is located on the main range between $4^{\circ} 20^{\prime \prime} \mathrm{N}-4^{\circ} 37^{\prime \prime} \mathrm{N}$ and $101^{\circ} 20^{\prime \prime}-101^{\circ} 36^{\prime \prime} \mathrm{E}$. The Cameron Highlands' mean temperature is between $17^{\circ} \mathrm{C}$ and $20^{\circ} \mathrm{C}$ all year round, situated on a highland elevation. However, local temperatures rose to $5^{\circ} \mathrm{C}$ in 2014, relative to the last 15 years (RTD 2003). The maximum rainfall (wet season) is from April to May and October to November, while January to March and June to August have the minimum rainfall (dry season). The mean elevation of the study site is $1404.5 \mathrm{~m}$ above sea level.

2.2. Experimental Design. The experiment was designed in a randomized complete block design (RCBD) with four replicates. The four treatments include

(i) Coconut mulching treatment (CM)

(ii) Plastic mulching treatment (PM)

(iii) Oil palm mulching treatment (OM)

(iv) Control treatment without any cover (CK)

Only one plant species, namely, Magnolia champaca, was used in this study. Each treatment contains four rows of 10 trees, which is 40 trees in total. The space between rows and plants was $4 \mathrm{~m} \times 4 \mathrm{~m}$, with a total of 160 trees (4 treatments $\times 40$ trees each).

2.3. Soil Sampling and Analysis. The soil was collected at a depth of $20 \mathrm{~cm}$ at four random positions in each plot. In each treatment, eight samples were taken from below the mulch layer in the plots where the mulch was added. There were 32 soil samples gathered and analysed in total. Soil samples were air-dried at room temperature and then sieved through a $2 \mathrm{~mm}$ sieve. After sieving, the physical and chemical properties of the collected soils were determined. The pipette method was used to determine soil texture [23]. Soil compaction was measured by UTS-0075 Pocket Dial Penetrometer (range $0-6,0-11 \mathrm{~kg} / \mathrm{cm})$ on the topsoil $(0-5 \mathrm{~cm})$ once at the end of data collection. Available $P$ value was determined with a spectrophotometer using the Olsen method [24]. Soil organic $\mathrm{C}$ was determined using the Walkley-Black technique [25]. The $\mathrm{pH}$ was determined by an Orion Analyzer (Model 901) $\mathrm{pH}$ meter in a soil:water ratio of $1: 2.5$. Total $N$ was measured using the Kjeldahl method [26]. The soil moisture content was determined by the gravimetric method [27]. 


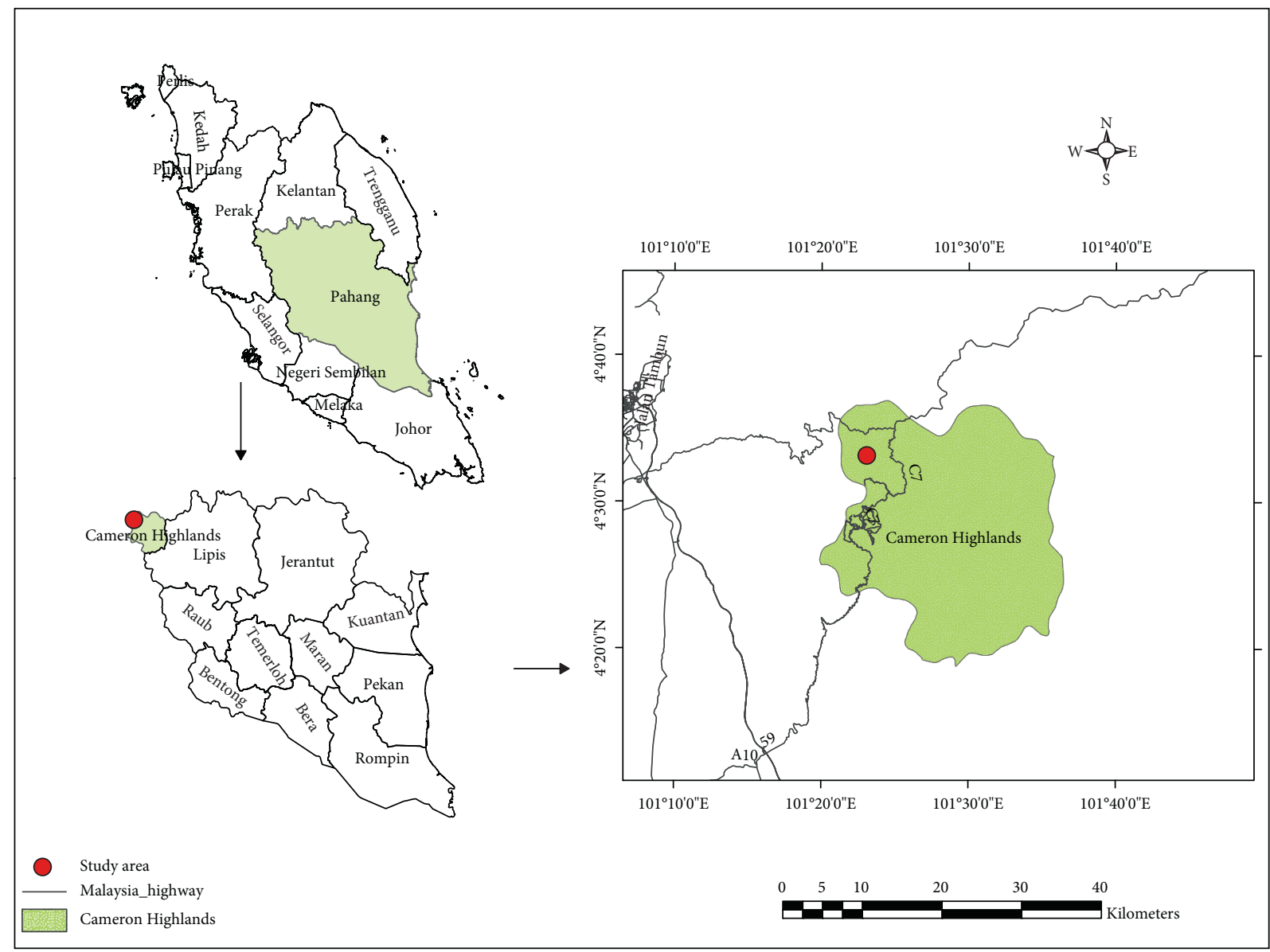

Figure 1: Study site located in Terla Forest Reserve Cameron Highlands, Pahang, Malaysia.

Exchanged potassium was determined by flame atomic emission spectrometry (AES), and the turbidimetric method was used to determine the total sulphur [28].

2.4. Tree Growth. The survival of trees was recorded twice at the beginning and the end of the study. Meanwhile, we took the growth performance of $M$. champaca on the fourth week of every month for one year (July 2019-July 2020). A telescopic measuring pole recorded seedlings' height. In the meantime, we measured root collar diameter at $10 \mathrm{~cm}$ and diameter breast height at $130 \mathrm{~cm}$ above the soil with a Digital Vernier Caliper (Mitutoyo UK Ltd., Hampshire, UK).

We determined the chlorophyll content of the SPAD 502 Plus Chlorophyll Meter (Spectrum Technologies Inc., Aurora, IL) between 8:00 a.m. and 11:00 a.m. The leaves are found in the centre of the third vine. From each tree, we chose three leaves to compose the repetition, and the average was recorded.

2.5. Root System. We used the excavation method for the root system, and digging took place from the trunk, which was removed for safety purposes, with the incremental removal of the soil layer by layer before finding the first main roots. Standard excavation tools have been used to prevent root destruction. After uncovering the first layer of horizontally growing roots, a grid of rope was spread across the soils surface. The width of the grids was $10 \times 10 \mathrm{~cm}$. We mounted a wooden framework directly above the grid net to provide convenient access to all parts of the root system, and rood diameter, lateral root length, main root depth, root coiling, and root direction were recorded for each seedling moreover the root system direction [29].

2.6. Data Analysis. The experimental design was randomized complete block design, whereby plots were randomly assigned to the treatments. Generalized linear modelling (GLM, oneway analysis of variance) was applied to relate growth performance and soil properties responses with treatment. When the ANOVA analysis found significant differences between treatments, post hoc comparisons of the treatment group means were performed using Tukey test with a 95\% confidence level. Treatment effects were considered statistically significant when $p \leq 0.05$. SPSS (release 17.0; Chicago, IL, USA) statistical package was used for analyses. All statistical analyses were performed at a 95\% confidence level.

\section{Results}

3.1. Effect of Different Types of Mulches on Survival, Growth Performance, and Chlorophyll Content. In this study, plant survival, plant height, root collar diameter, and diameter at 
breast height were monitored as growth parameters. Based on the observation during 12 months of study, M. champaca showed $100 \%$ survival between treatments. The variance analysis (Table 1) revealed that plant height, root collar diameter, and diameter at breast height of $M$. champaca were not affected by different mulching types. None of the treatments increased the plant height, root collar diameter, and diameter at breast height significantly. Plant height in $\mathrm{OM}$ indicates the highest increment grown in $1.47 \mathrm{~m}$ and slightly higher than PM $(1.43 \mathrm{~m})$, CK $(1.43 \mathrm{~m})$, and CM $(1.42 \mathrm{~m})$, respectively (Figure 2$)$. The breast height diameter was greater in OM $(1 \mathrm{~cm})$ than $\mathrm{CM}(0.98 \mathrm{~cm})$. We found the lowest diameter breast height value in PM between different treatments (Figure 2). OM's root collar diameter showed a greater value of $2.36 \mathrm{~cm}$ and the lowest value of $2.25 \mathrm{~cm}$ was recorded in PM (Figure 2). Hence, OM had a greater effect on plant height, root collar diameter, and diameter at breast height on M. champaca than CM, PM, and CK. Chlorophyll content was measured as growth performance for Magnolia spp. The data (Figure 3) show none of the mulching treatments significantly affected chlorophyll content, although PM showed the highest chlorophyll content 21.3 compared to OM (19.9), CM (19.8), and CK (19.16), respectively.

3.2. Root Development. In this study, the root diameter was recorded during the study as root development parameters. Results show (Figure 4) there was a significant difference between treatments. We found the highest root diameter grown increment $(0.66 \mathrm{~cm})$ in $\mathrm{CM}$, and it was higher than $\mathrm{OM}(0.50 \mathrm{~cm}), \mathrm{PM}(0.39 \mathrm{~cm})$, and CK $(0.38 \mathrm{~cm})$ treatments, respectively. The lowest root diameter increment was recorded in CK. The lateral root length increment did not show a significant difference among different mulching treatments (Figure 4). The highest lateral root length increment is showed in CM $(65.83 \mathrm{~cm})$ and slightly higher than PM $(64.70 \mathrm{~cm})$, CK $(62 \mathrm{~cm})$, and OM $(59.42 \mathrm{~cm})$ respectively. There was a significant difference between treatments for main root length increment. CM treatment was significantly higher than PM and CK treatments, but there was no significant difference between $\mathrm{CM}$ and $\mathrm{OM}$ treatments. The main root length increment in CM treatment was slightly higher than $\mathrm{OM}(41.33 \mathrm{~cm}), \mathrm{CK}$ $(37.76 \mathrm{~cm})$, and $\mathrm{PM}$ treatment $(36.67 \mathrm{~cm})$, respectively (Figure 4).

The root direction was significantly different from the sun directions. The direction of the roots varied toward the sun between directions. Results show (Figure 5) that 35\% of roots were toward the north, $14.7 \%$ south, $14.7 \%$ west, $11.76 \%$ south-west, $8.82 \%$ east, $8.82 \%$ north-west, $2.94 \%$ northeast, and $2.94 \%$ south-west, respectively. On the other hand, $35 \%$ of the root system were toward the north direction. Moreover, there was no correlation between root direction and soil compaction among treatments. The horizontal and vertical roots were significantly different between treatments (Figure 6). The horizontal roots were significantly higher in CM $(65.8 \mathrm{~cm})$ than PM $(64.7 \mathrm{~cm}), \mathrm{CK}$ $(62 \mathrm{~cm})$, and $\mathrm{OM}(59.4 \mathrm{~cm})$ treatments, respectively. In other words, CM $(65.8 \mathrm{~cm})$ treatment showed the highest value and $\mathrm{OM} 59.4 \mathrm{~cm}$ treatment showed the lowest value among treatments. Moreover, the root system in the vertical direction $\mathrm{CM}(49 \mathrm{~cm})$ treatment compared to $\mathrm{OM}(41.3 \mathrm{~cm})$, CK $(37.6 \mathrm{~cm})$, and PM $(36.6 \mathrm{~cm})$ treatments showed higher horizontal root distribution, respectively. The root distribution was affected by $\mathrm{CM}$ in horizontal and vertical directions between different types of mulching treatment.

Results (Figure 7) show there was no significant difference between treatments for root/shoot ratio. Compared between treatments, OM treatment $(3.40 \mathrm{~g})$ was significantly higher than CM (3.17g), PM (2.85 g), and CK (2.11 g) treatments, respectively. Moreover, significant coiling was observed for Magnolia spp. after three years. The root pictures show $75 \%$ of the tree had significant coiling, and $25 \%$ show no coiling among trees.

3.3. Effect of Different Types of Mulches on Soil Physical Properties. The results indicate that the soil colour was between yellow and brownish-yellow for all treatments. There was no significant difference in soil texture between treatments. The soil content was $60 \%$ of silt, $20 \%$ clay, and $20 \%$ sand for all blocks and treatments. Therefore, the soil texture was silt loam among blocks and treatments. There has been a significant difference in soil compaction for various types of mulching. The maximum value of soil compaction was shown in CK, while the minimum value was in $\mathrm{CM}$ treatment. In another word, CK showed higher $\left(2.46 \mathrm{~kg} / \mathrm{cm}^{3}\right)$ compacted soil than PM $\left(2.05 \mathrm{~kg} / \mathrm{cm}^{3}\right), \mathrm{OM}$ $\left(1.79 \mathrm{~kg} / \mathrm{cm}^{3}\right)$, and CM $\left(0.94 \mathrm{~kg} / \mathrm{cm}^{3}\right)$ treatments, respectively (Figure 8).

3.4. Effect of Different Types of Mulches on Soil Chemical Properties. The $\mathrm{pH}$ value was significantly different between treatments (Figure 9 and Table 2). We found the minimum $\mathrm{pH}$ value in $\mathrm{PM}(4.28 \mathrm{pH})$, and the maximum value was found in CM (4.57 pH). In other words, there was a highly significant difference between $\mathrm{CM}$ and $\mathrm{OM}$ treatments, while there was no significant difference between CM and PM treatments. The difference in soil moisture content (Figure 9 and Table 2) was highly significant between treatments. Soil moisture in PM (17.92\%) was significantly higher than CM (17\%), CK (16.16\%), and OM (16.12\%) treatments. There was no significant difference between treatments for soil organic carbon (Figure 10 and Table 2). PM treatment $(0.13 \%)$ was slightly higher than OM $(0.09 \%)$, CM $(0.05 \%)$, and CK $(0.04 \%)$, respectively. Moreover, different mulching did not lead to a significant difference in available phosphorus between treatments (Figure 9). PM (4.59 ppm) showed a greater value than CM (3.96 ppm), CK (3.26 ppm), and OM (3.23 ppm) between treatments, respectively. However, mulching had a significant effect on the exchange of potassium between treatments (Figure 10 and Table 2). We found the highest value in CM (0.07) compared to $\mathrm{CK}(0.06), \mathrm{PM}$, and OM (0.05) treatments, respectively. There was no significant difference between treatments for total nitrogen (Figure 10 and Table 2). CM treatment $(0.05 \%)$ showed greater value of total nitrogen than PM 
TABLE 1: ANOVA table for plant height, root collar diameter, and diameter at breast height.

\begin{tabular}{|c|c|c|c|c|c|c|}
\hline & & Sum of squares & $\mathrm{df}$ & Mean square & $F$ & Sig. \\
\hline \multirow{3}{*}{ Plant height } & Between groups & 544.24 & 3.00 & 181.41 & 0.12 & 0.95 \\
\hline & Within groups & 232775.36 & 156.00 & 1492.15 & & \\
\hline & Total & 233319.60 & 159.00 & & & \\
\hline \multirow{3}{*}{$\mathrm{RCD}$} & Between groups & 36.28 & 3.00 & 12.09 & 0.23 & 0.87 \\
\hline & Within groups & 8085.98 & 156.00 & 51.83 & & \\
\hline & Total & 8122.26 & 159.00 & & & \\
\hline \multirow{3}{*}{$\mathrm{DBH}$} & Between groups & 24.60 & 3.00 & 8.20 & 0.83 & 0.48 \\
\hline & Within groups & 1132.22 & 114.00 & 9.93 & & \\
\hline & Total & 1156.82 & 117.00 & & & \\
\hline
\end{tabular}

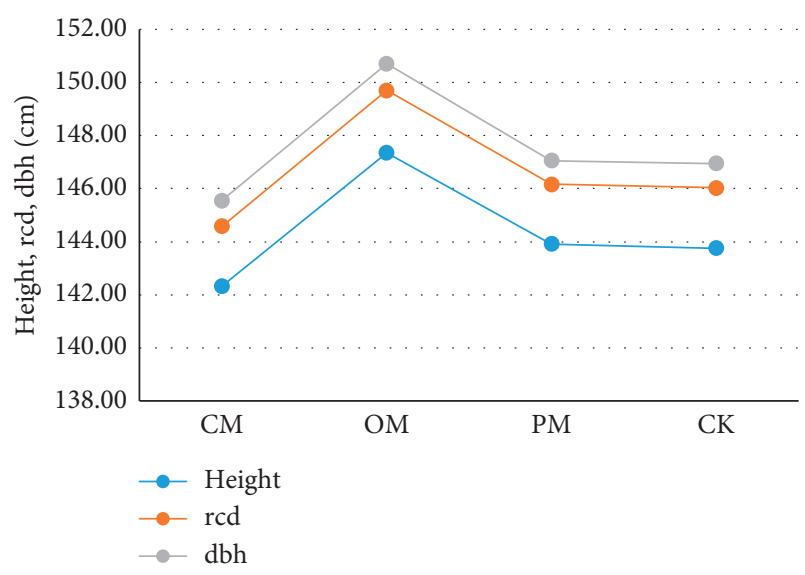

FIGURE 2: Plant height, root collar diameter (RCD), and diameter at breast height $(\mathrm{DBH})$.

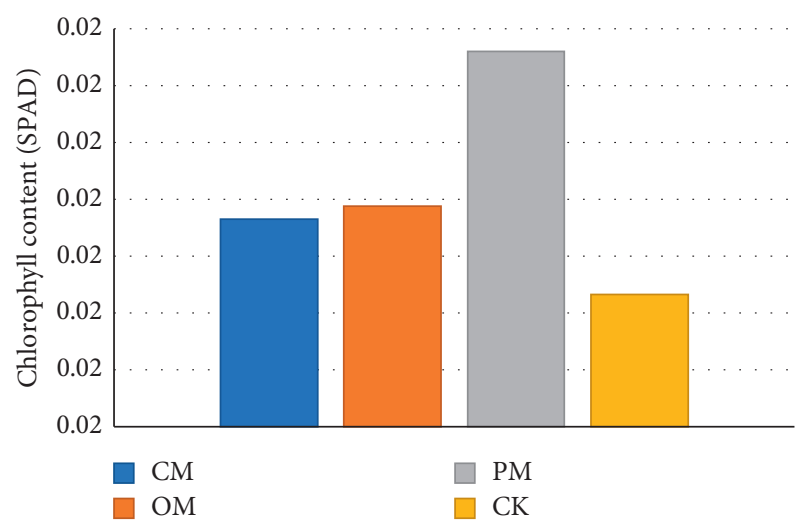

FIGURE 3: Chlorophyll content of Magnolia spp. under different mulching.

(0.03\%), CK (0.03\%), and OM (0.02\%) between treatments. Based on Figure 10, there was a highly significant difference for total sulphur between treatments. We found the highest value in CM treatment and PM $(0.02 \%)$ than $\mathrm{CK}$ and OM $(0.01 \%)$ treatments.

\section{Discussion}

4.1. Tree Growth. The application of different mulching had different effects on tree growth. Several studies indicated that mulching had no significant impact on tree growth [30-32].

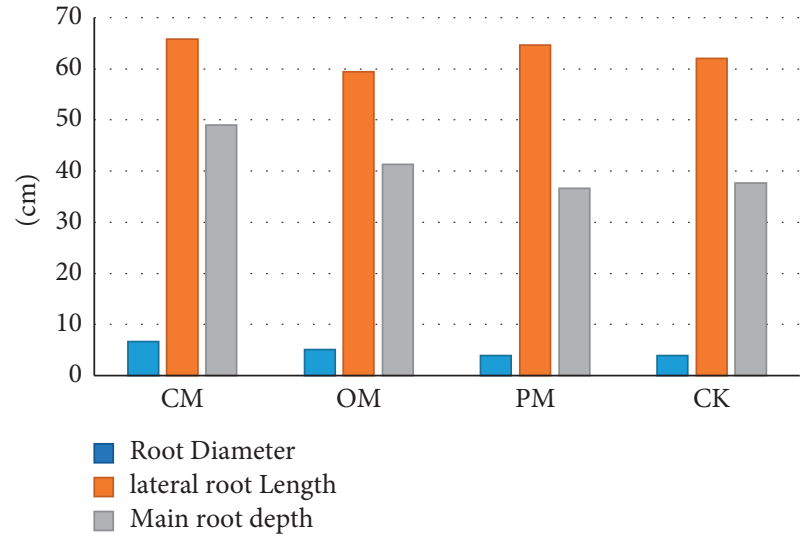

FIGURE 4: Root diameter, lateral root length, and main root depth.

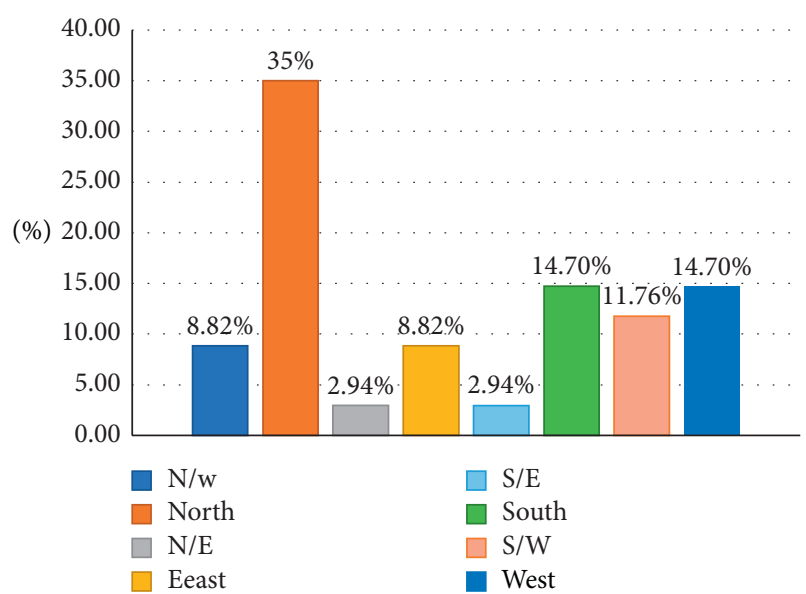

FIgURe 5: Root distribution toward the sun.

Many studies have demonstrated that mulching, especially with organic mulching, can improve tree growth [33-35]. Moreover, previous studies $[34,36]$ indicate that mulching did not significantly affect the diameter at breast height, although mulching had greater value than the bare soil. The root collar diameter studies have shown that mulching did not significantly influence root collar diameter (RCD) growth [37, 38]. However, several studies found that organic mulching affected root collar diameter compared to inorganic mulching [8, 30]. Moreover, Amin et al. [35] found 


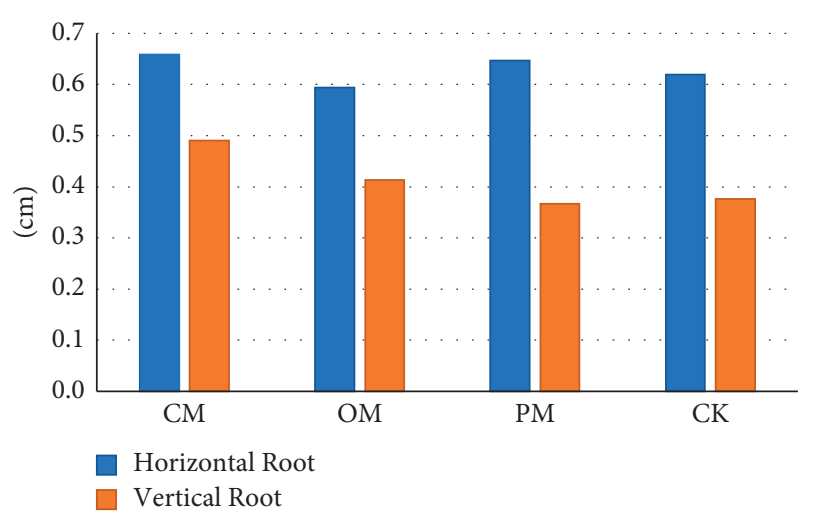

Figure 6: Horizontal and vertical root development.

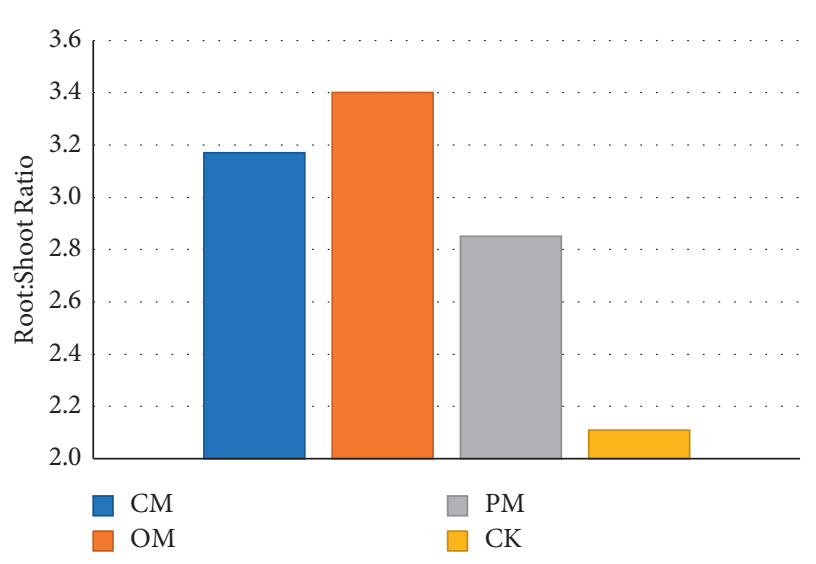

FIGURE 7: Root-shoot ratio among treatments.

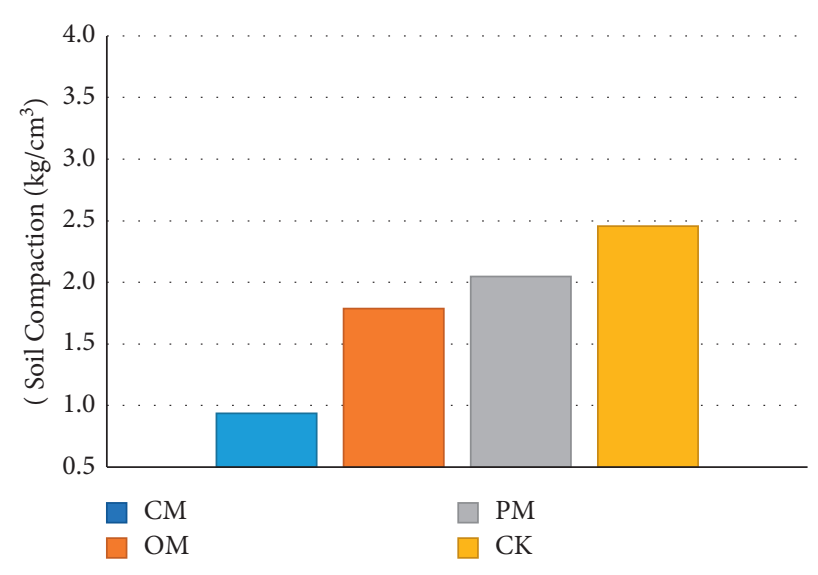

Figure 8: Soil compaction under different mulching.

that mulching treatments significantly affected the stem diameter of coffee seedlings compared to no-mulching. However, the present study agreed with the earlier studies and indicates that organic mulching did not show significant effect, although mulching treatments improved plant height, diameter at breast height, and root collar diameter. The growth of Magnolia spp. enhanced by the mulched treatments could be attributed to the fact that mulching provides favourable conditions for growth and development of the plant by providing improved soil moisture conservation,

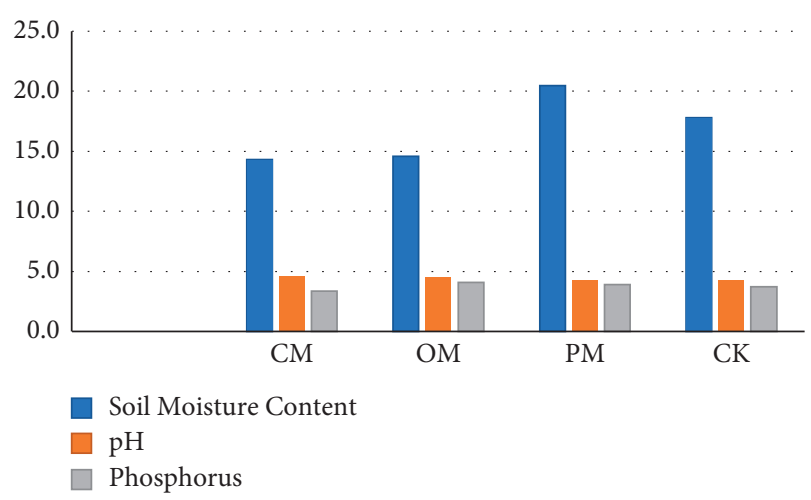

FIgURE 9: Soil moisture content, pH, and available phosphorus.

reduced soil temperature, and reduced weed infestation and nutrient availability as a result of reduced leaching of nutrients. For the chlorophyll content, several studies have reported that black plastic mulching results in a greater value of chlorophyll content than control treatment [39-41]. Marichamy et al. [42] and Yang et al. [43] reported that black plastic mulching had the highest value of chlorophyll than organic mulches and found the lowest value of the control treatment. Zhang et al. [44] also reported that straw mulching significantly increased the chlorophyll content compared to no mulching. The beneficial impact of polyethylene mulching on photosynthetic pigments may be attributed to the hypothesis that light reaction of photosynthesis is an important compound of Chlorophyll A. Chlorophyll B is a light-harvesting pigment who's absorbed light energy has been converted to Chlorophyll A [45]. Besides, the increase in total chlorophyll according to the use of black plastic mulch might be because plastic mulching improves the microbial population of the soil and increases the absorption of nitrogen and hence the plant leaves chlorophyll content [46]. The present study, combined with the earlier studies, indicates that black plastic mulching had a better effect on chlorophyll content than organic mulching and organic mulching had a better effect than control.

4.2. Root Development. The roots' ability to explore the underground ecosystem in forest settings influences tree fitness, stability, and survival. Previous studies demonstrated that lateral root diameter increased under different types of mulching [47, 48]. Gao et al. [49] found that plastic mulching had a greater effect on root diameter than control. Moreover, Bécel et al. [50] stated that with soil penetration resistance, the mean diameters dramatically increased. An improvement in the ratio reveals that the lateral root diameter improves more than the parent's root diameter. However, this study indicates that root diameter in organic mulching treatments had better growth, probably due to more organic matter, less soil compaction, and high soil carbon than no-mulching treatments. Gough [51] demonstrated that plastic mulch had a better effect on lateral roots than bare soil. Moreover, Schenk and Jackson [52] demonstrated that annual succulents had larger lateral root 
TABLE 2: Physical and chemical properties of soil under different types of mulching experiments.

\begin{tabular}{lccccccc}
\hline Treatments & $\mathrm{pH}$ & $\begin{array}{c}\text { Soil moisture } \\
\text { content }(\%)\end{array}$ & $\begin{array}{c}\text { Soil organic } \\
\text { carbon }(\%)\end{array}$ & Total $S(\%)$ & Total $N\left(\mathrm{~g} \mathrm{~kg}^{-1}\right)$ & Available $P\left(\mathrm{mg}^{2} \mathrm{~kg}^{-1}\right)$ & Exchange $K\left(\mathrm{cmol} / \mathrm{kg}^{2}\right)$ \\
\hline $\mathrm{CM}$ & $4.59 \pm 0.15$ & $14.32 \pm 1.09$ & $0.14 \pm 0.22$ & $0.01 \pm 0.00$ & $0.05 \pm 0.04$ & $3.34 \pm 0.71$ & $0.10 \pm 0.04$ \\
$\mathrm{OM}$ & $4.51 \pm 0.15$ & $14.60 \pm 1.10$ & $0.07 \pm 0.06$ & $0.01 \pm 0.00$ & $0.02 \pm 0.04$ & $4.08 \pm 1.88$ & $0.09 \pm 0.05$ \\
$\mathrm{PM}$ & $4.28 \pm 0.13$ & $20.49 \pm 3.52$ & $0.04 \pm 0.03$ & $0.02 \pm 0.01$ & $0.01 \pm 0.00$ & $3.88 \pm 2.17$ & $0.04 \pm 0.02$ \\
$\mathrm{CK}$ & $4.31 \pm 0.26$ & $17.78 \pm 0.90$ & $0.07 \pm 0.02$ & $0.02 \pm 0.00$ & $0.05 \pm 0.05$ & $3.73 \pm 3.73$ & $0.02 \pm 0.01$ \\
\hline
\end{tabular}

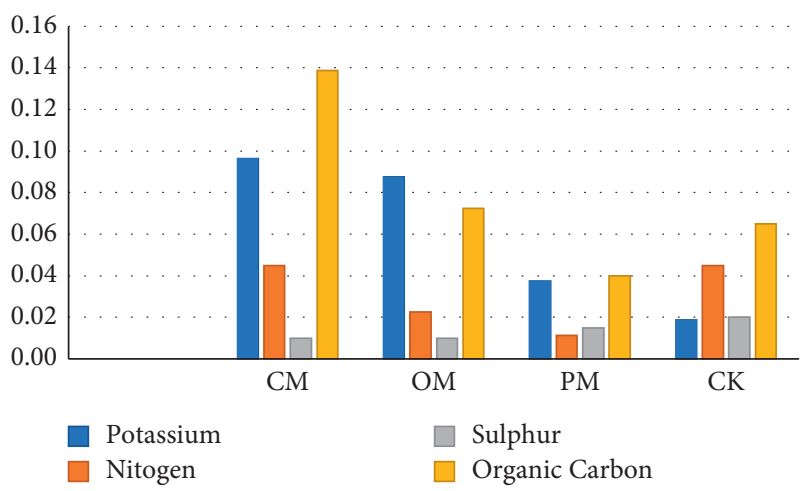

Figure 10: Exchange potassium, total nitrogen, total sulphur, and soil organic carbon.

spreads than rooting depths in water-limited ecosystems. This study found that lateral root length in organic mulching treatments was higher and it may be due to more soil moisture content, organic matter, and soil carbon and less compaction in the topsoil than control treatments. Main root length is a stronger root growth metric compared to the absorption of water and nutrients, as a high root length is associated with a short distance of water and solutes [53]. The early studies $[48,49,54,55]$ indicated that root length increment was higher in mulching treatment, especially in organic mulches than bare soil. However, these study findings are by the earlier studies that main root length decreased in control treatments. The key factors are presumably due to the limitations of gas diffusion [56], the higher accumulation of $\mathrm{CO}_{2}$ in the topsoil [57], and lower soil respiration rate [56], which contributes to reducing root respiration and microbial activity across the root system [58]. When roots expand through the soil, they must either follow pores or canals or infiltrate and displace the soil layer. Mechanical impedance refers to the resistance against deformation given by the soil matrix and has a major impact on root growth [59]. Root elongation is increasingly delayed as soil impedance rises due to naturally high bulk density, soil dryness, or soil compaction [60]. Nevertheless, roots are growing where the resources of life are available. They are not rising toward anything. Generally, if there is little oxygen or where the soil is compacted and difficult to penetrate, they do not grow [61]. Root development is opportunistic, only if the soil condition will support it [62]. Tree roots are the key contributors to soil structure development and, in the longer term, to soil composition. The most significant root concentration is located at the soil surface where the soil is loose, and water, oxygen, and nutrients are most easily accessible [62]. Thidar et al. [63] and Yao et al. [54] observed that most vertically found roots were in organic and plastic mulching treatments at the top $0-30 \mathrm{~cm}$ soil depth and horizontally $0-15 \mathrm{~cm}$ distance from the plant foundation. Also, Schenk and Jackson [52] reported annual succulents had very shallow rooting depths. Still, sizeable lateral root spreads in water-limited ecosystems; therefore, the present result is consistent with those of Chalker-Scott, [64] who found that in soil treated with organic mulches, root growth density is more significant than in those treated with nothing or plastic.

The volume of the root system and the root/shoot ratio demanded the supply of nutrients, water, and the chemical, physical, and biological properties of the substrate that affect root growth and new roots. Thidar et al. [65] and Zhang et al. [66] indicated that mulching especially organic mulching had a significant effect on root/shoot ratio compared to control treatment. The root/shoot ratio is related to the nutrient supply/fertilization ratio, with a higher ratio at low nutrient supply [60]. Moreover, Agele et al. [67] pointed out that the root/shoot ratio did not reveal any significant values in both trials (first and second years) with the highest values obtained from soil plots. However, this study's findings attribute to the level of resources, as Ong and Julia [68] stated that with increased resources, both shoot and root biomass increases, but the maximum root biomass is typically obtained at a lower resource level than maximum shoot biomass. Hence, according to the availability of resources, the shoot:root ratio changes. Root coiling happens when seedlings are left too long in the greenhouse; the roots do not find any way to extend their way down in the restricted area. Davis and Jacobs [69] stated that poly bags and plastic containers experienced low seedling growth and root coiling. However, the seedlings root coiling was due to using small size of poly bags in the nursery, old seedlings, and poor management practices.

4.3. Soil Physical Properties. Cameron Highlands soil texture is mainly derived from granite, sandy to sandy clay loamy [70]. However, silt loam has a medium infiltration rate, modest water-holding capacity available for plants, and nonrestricted root growth and is highly susceptible to compaction. Besides, the silt loam's texture is highly susceptible to water erosion and hardening [71]. Moderate phosphorus fixation, low plant available water, and soil compaction are the characteristic of these soil colours [71]. Many studies have reported that mulches had significant advantages in bulk density and soil compaction [72, 73]. Moreover, soil compaction makes skid trails inhospitable to the roots in water and oxygen availability and can contribute 
to a long-term decline in natural regeneration [74]. The findings of this study are consistent with the general observations that the addition of litter mulch to compacted surface soils could accelerate regeneration and improve the physical properties of the soil by improving soil quality and stimulating biological activity [75].

4.4. Soil Chemical Properties. The previous studies have found that organic mulching significantly decreases soil $\mathrm{pH}$ $[76,77]$. Also, many studies have found that organic and inorganic mulching increased soil $\mathrm{pH}[11,78]$. The results of the present study were synonymous with these reports. However, low $\mathrm{pH}$ levels may result in a lack of basic elements such as $\mathrm{Ca}, \mathrm{Mg}, \mathrm{K}$, and $\mathrm{N}$ in the soil. These results with this study indicate that the impact of mulches on soil $\mathrm{pH}$ relies on the mulching content and the soil composition/type. Previous studies have generally indicated that mulches, including plastics, gravel, barks, wood chips, and grass can maintain soil moisture content by reducing the rate of evaporation [79-82]. However, soil moisture content in inorganic mulching was higher than organic mulches $[30,83]$. Moreover, our findings demonstrate that the plastic mulching resulted in higher soil moisture than organic mulches. This might be because organic mulching (CM and $\mathrm{OM}$ ) increased the rate of evaporation. Besides, organic mulching is hygroscopic, and therefore, they tend to absorb water from the soil, which in turn lowered the soil moisture. On the contrary, plastic mulching prevents soil exposure to solar radiation, and its resistance to the passage of water has decreased soil evaporation. Also, mulches reduce impact of raindrops and splash, thereby preventing soil compaction, reducing surface run-off, and increasing water infiltration. All these were combined to increase the soil moisture content and reduce moisture depletion. Bai et al. [83] revealed that inorganic and organic mulches had no significant effect on soil organic carbon. However, this study's finding is in line with the earlier studies [30,84-86] and confirmed that organic mulching improves the soil organic carbon due to the accumulation of carbonaceous material. Organic mulch can improve the soil's organic carbon because organic mulches provide carbonaceous material to the soil upon decomposition. Many studies have demonstrated that mulching significantly affected the available $\mathrm{P}$ in different soil depths and surfaces [60, 80]. Qu et al. [30] indicated that available phosphorus content was significantly affected only by the organic mulches. Although Kumar et al. [87] demonstrated that available $\mathrm{P}$ was recorded significantly highest in black plastic in the first year. Both mulch treatments were statistically on average with each other during the second year. It can be due to improved hydrothermal regimes, more root system proliferation, and effective management of weeds that have reduced $\mathrm{P}$ mining. Previous studies $[22,87,88]$ indicated that the level of soil potassium in organic mulches treatment increased compared to bare soil. Also, Jourgholami et al. [74] demonstrated that potassium's lowest value was found in bare soil and higher in the undisturbed area in compacted soil. However, the improvement in the $\mathrm{K}$ content of mulching soils may be attributed to increased removal of competing weeds, enhanced hydrothermal regime, and higher root biomass releases of potassium to the soil. Early studies found that total nitrogen increased in organic mulching than bare soil $[6,75]$. The improvement in total nitrogen under mulch is consistent with the earlier studies that mulching resulted in significantly higher soil organic $\mathrm{N}$ mineralization, residual accumulation of nitrate in the soil profile, and decrease of soil profile $\mathrm{N}$ depletion. Saroa and Lal [89] reported mulch rate had no effect on the total sulphur concentration of particle size fractions for either mulching duration, but generally decreased with depth. Haque et al. [90] found that the highest sulphur contents were in bare soil (control) treatment in both years. However, in the present study, the sulphur was high in mulching treatments. It might be because majority of sulphur in soil is present in organic forms and not readily available for plant uptake.

\section{Conclusions}

The various mulching materials had a different effect on plant growth, root system and, soil properties. Our findings indicate that mulching did not significantly affect soil properties. However, mulches help create a healthy soil environment, especially organic mulches (coconut mulch and oil palm mulch), and various mulches have different effects on the soil properties. Soil moisture content, total sulphur, $\mathrm{pH}$, and exchange potassium increased significantly between treatments. Moreover, mulching had a significant effect on root diameter, main root length, and root distributions.

In comparison, mulching did not significantly affect total nitrogen, available phosphorus, soil organic carbon, plant height, root collar diameter, diameter at breast height, chlorophyll content, lateral root length, and root:shoot ratio. OM mulching had a better effect on plant height, root collar diameter, and diameter at breast height. However, PM had a better effect on chlorophyll content among treatments and CM had a better effect on plant root system development. Therefore, considering the effect of mulching on soil properties, plant growth, and physiology, coconut mulching and oil palm mulching are better than plastic and bare soil in the degraded area at tropical rainforest plantation. Further studies are required to determine the long-term effect of mulching on the tropical restoration area.

\section{Data Availability}

All data used will be available on the corresponding author's research gate page and also will be made available when requested.

\section{Conflicts of Interest}

The authors declare that they have no conflicts of interest.

\section{Acknowledgments}

The authors would like to thank Dato' Mohd Ridza Awang (Director General, Forestry Department of Peninsular 
Malaysia) and Mr. Mohd Fakhri Ishak (Forest Research Institute Malaysia) for their contributions during data collection and the ideas developed for this paper. This research was funded by Forestry Department of Peninsular Malaysia.

\section{References}

[1] J. M. Davis, "Comparison of mulches for fresh-market basil production," HortScience, vol. 29, no. 4, pp. 267-268, 1994.

[2] S. Fang, B. Xie, D. Liu, and J. Liu, "Effects of mulching materials on nitrogen mineralization, nitrogen availability and poplar growth on degraded agricultural soil," New Forests, vol. 41, no. 2, pp. 147-162, 2011.

[3] A. A. Maynard, "Utilization of MSW compost in nursery stock production," Compost Science \& Utilization, vol. 6, no. 4, pp. 38-44, 1998.

[4] M. A. Kader, M. Senge, M. A. Mojid, and K. Ito, "Recent advances in mulching materials and methods for modifying soil environment," Soil and Tillage Research, vol. 168, pp. 155-166, 2017.

[5] X. Ni, W. Song, H. Zhang, X. Yang, and L. Wang, "Effects of mulching on soil properties and growth of tea olive (Osmanthus fragrans)," PLoS One, vol. 11, no. 8, Article ID e0158228, 2016.

[6] X. Qian, J. Gu, H.-j. Pan et al., "Effects of living mulches on the soil nutrient contents, enzyme activities, and bacterial community diversities of apple orchard soils," European Journal of Soil Biology, vol. 70, pp. 23-30, 2015.

[7] H. Zhao, R.-Y. Wang, B.-L. Ma et al., "Ridge-furrow with full plastic film mulching improves water use efficiency and tuber yields of potato in a semiarid rainfed ecosystem," Field Crops Research, vol. 161, pp. 137-148, 2014.

[8] A. Fini, C. Degl'Innocenti, and F. Ferrini, "Effect of mulching with compost on growth and physiology of Ulmus "FL634" planted in an urban park," Arboriculture \& Urban Forestry, vol. 42, pp. 192-200, 2016.

[9] J. S. Samra and S. C. Singh, "Evaluation of an Acacia nilotica based silvipasture system on degraded land of Shivalik foothills," Indian Journal of Soil Conservation, vol. 26, pp. 226-233, 1998.

[10] J. Downer and D. Hodel, "The effects of mulching on establishment of Syagrus romanzoffiana (Cham.) Becc., Washingtonia robusta $H$. Wendl. and Archontophoenix cunninghamiana ( $\mathrm{H}$. Wendl.) $\mathrm{H}$. Wendl. \& Drude in the landscape," Scientia Horticulturae, vol. 87, no. 1-2, pp. 85-92, 2001.

[11] A. Cahill, L. Chalker-Scott, and K. Ewing, "Wood-chip mulch improves plant survival and establishment at no-maintenance restoration site (Washington)," Ecological Restoration, vol. 23, pp. 212-213, 2005.

[12] H. Hopp and G. B. Posey, "Evaluation of cork oak as a new farm tree crop in the southeastern United States," The Bulletin of the Ecological Society of America, vol. 23, p. 73, 1942.

[13] J. B. Calkins, B. T. Swanson, and D. L. Newman, "Weed control strategies for field grown herbaceous perennials," Journal of Environmental Horticulture, vol. 14, no. 4, pp. 221-227, 1996.

[14] W. Pfammatter and A. Dessimoz, "Influence de l'irrigation et de la couverture du sol sur le developpement et le rendement de jeunes pommiers (influence of irrigation and ground cover on development and yields of young apple trees)," Revue Suisse de Viticulture, d'Arboriculture et d'Horticulture, vol. 29, pp. 301-304, 1997.
[15] A. D. Munir, N. M. Majid, I. Abdol, and G. S. Khan, "Effects of mulching on the growth of interplanted Acacia mangium on sandy tin-tailings in Peninsular Malaysia," Lyallpur Akhbar, vol. 65, p. 3, 1998.

[16] Y. Tilander and M. Bonzi, "Water and nutrient conservation through the use of agroforestry mulches, and sorghum yield response," Plant and Soil, vol. 197, no. 2, pp. 219-232, 1997.

[17] J. B. Fausett and C. R. Rom, "The effects of transitioning a mature high-density orchard from standard herbicide ground-cover management system to organic ground-cover management systems," Arkansas Agricultural Experiment Station Research Series, vol. 483, pp. 33-36, 2001.

[18] P. J. Burgess, J. C. Nkomaula, and A. L. Medeiros-Ramos, "Root distribution and water use in a four-year old silvoarable system," Agroforestry Forum, vol. 8, pp. 15-18, 1997.

[19] R. Bhatt and K. L. Khera, "Effect of tillage and mode of straw mulch application on soil erosion in the submontaneous tract of Punjab, India," Soil and Tillage Research, vol. 88, no. 1-2, pp. 107-115, 2006.

[20] P. Pramanik, K. K. Bandyopadhyay, D. Bhaduri, R. Bhattacharyya, and P. Aggarwal, "Effect of mulch on soil thermal regimes-a review," International Journal of Agriculture Environment \& Biotechnology, vol. 8, no. 3, pp. 645-658, 2015.

[21] M. McMillen, The Effect of Mulch Type and Thickness on the Soil Surface Evaporation Rate, California Polytechnic State University, San Luis Obispo, California, 2013.

[22] S. Nwosisi, D. Nandwani, and D. Hui, "Mulch treatment effect on weed biomass and yields of organic sweetpotato cultivars," Agronomy, vol. 9, no. 4, p. 190, 2019.

[23] G. F. Coates and C. A. Hulse, "A comparison of four methods of size analysis of fine-grained sediments," New Zealand Journal of Geology and Geophysics, vol. 28, no. 2, pp. 369-380, 1985.

[24] M. Iatrou, A. Papadopoulos, F. Papadopoulos, O. Dichala, P. Psoma, and A. Bountla, "Determination of soil available phosphorus using the olsen and mehlich 3 methods for Greek soils having variable amounts of calcium carbonate," Communications in Soil Science and Plant Analysis, vol. 45, no. 16, pp. 2207-2214, 2014.

[25] A. Walkley and I. A. Black, "An examination of the Degtjareff method for determining soil organic matter, and a proposed modification of the chromic acid titration method," Soil Science, vol. 37, no. 1, pp. 29-38, 1934.

[26] A. Salehi, N. Ghorbanzadeh, and E. Kahneh, "Earthworm biomass and abundance, soil chemical and physical properties under different poplar plantations in the north of Iran," Journal of Forest Science, vol. 59, no. 6, pp. 223-229, 2013.

[27] A. Shukla, H. Panchal, M. Mishra et al., "Soil moisture estimation using gravimetric technique and FDR probe technique: a comparative analysis," American International Journal of Research in Formal, Applied and Natural Sciences, vol. 8, pp. 89-92, 2014.

[28] L. L. Wall, C. W. Gehrke, and J. Suzuki, "An automated turbidimetric method for total sulfur in plant tissue and sulfate sulfur in soils," Communications in Soil Science and Plant Analysis, vol. 11, no. 11, pp. 1087-1103, 1980.

[29] T. C. E. Wells, "Methods of studying root systems," Biological Conservation, vol. 19, no. 2, 1981.

[30] B. Qu, Y. Liu, X. Sun et al., "Effect of various mulches on soil physi-co-chemical properties and tree growth (Sophora japonica) in urban tree pits," PLoS One, vol. 14, no. 2, Article ID e0210777, 2019. 
[31] A. Vincent and S. J. Davies, "Effects of nutrient addition, mulching and planting-hole size on early performance of Dryobalanops aromatica and Shorea parvifolia planted in secondary forest in Sarawak, Malaysia," Forest Ecology and Management, vol. 180, no. 1-3, pp. 261-271, 2003.

[32] A. Fini and F. Ferrini, "Effects of mulching with compost on growth and physiology of Acer campestre L. and Carpinus betulus L," Advances in Horticultural Science, vol. 25, no. 4, pp. 232-238, 2011.

[33] F. Ferrini, A. Fini, P. Frangi, and G. Amoroso, "Mulching of ornamental trees: effects on growth and physiology," Arboriculture \& Urban Forestry, vol. 34, no. 3, p. 157, 2008.

[34] M. Amin, A. Jaleta, and H. Bersisa, "Evaluation of mulching practice on the survival and subsequent early growth performances of the transplanted coffee seedlings," Universal Journal of Agricultural Research, vol. 6, no. 4, pp. 119-126, 2018.

[35] S. Fang, B. Xie, and J. Liu, "Soil nutrient availability, poplar growth and biomass production on degraded agricultural soil under fresh grass mulch," Forest Ecology and Management, vol. 255, no. 5-6, pp. 1802-1809, 2008.

[36] N. McCarthy, C. Mc Carthy, and M. O. Rathaille, Mulch Mats: Their Potential in Establishing Forest and Other Tree Crops, COFORD, National Council for Forest Research and Development, Dublin, Ireland, 2007.

[37] P. C. C. Lai and B. S. F. Wong, "Effects of tree guards and weed mats on the establishment of native tree seedlings: implications for forest restoration in Hong Kong, China," Restoration Ecology, vol. 13, no. 1, pp. 138-143, 2005.

[38] Y. Gao, Y. Li, Y. Wang et al., "Effect of different film color mulching on dry matter and grain yield of oil flax in dryland," Oil Crop Science, vol. 5, no. 2, pp. 17-22, 2020.

[39] A. A. Helaly, Y. Goda, A. A. S. El-Rehim, A. A. Mohamed, and O. A. H. El-Zeiny, "Effect of polyethylene mulch-ing type on the growth, yield and fruits quality of physalis pubescens," Advances in Plants \& Agriculture Research, vol. 6, no. 5, pp. 1-7, 2017.

[40] T. Sun, G. Li, T.-Y. Ning, Z.-M. Zhang, Q.-H. Mi, and R. Lal, "Suitability of mulching with biodegradable film to moderate soil temperature and moisture and to increase photosynthesis and yield in peanut," Agricultural Water Management, vol. 208, pp. 214-223, 2018.

[41] M. Marichamy, A. Thomas, J. Jayabharathi, A. Thomas, and V. Kanthaswamy, "Effect of different mulches on weed characters, chlorophyll and vitamin-C content of chilli (capsicum annuum L) hybrid sierra," Advances in Life Sciences, vol. 5, no. 4, pp. 1216-1219, 2016.

[42] Y.-m. Yang, L. Min, X.-j. Liu, W.-q. Li, and C.-z. Li, "Effect of different mulch materials on winter wheat production in desalinized soil in Heilonggang region of North China," Journal of Zhejiang University-Science B, vol. 7, no. 11, pp. 858-867, 2006.

[43] X. Zhang, Y. Qian, and C. Cao, "Effects of straw mulching on maize photosynthetic characteristics and rhizosphere soil micro-ecological environment," Chilean Journal of Agricultural Research, vol. 75, no. 4, pp. 481-486, 2015.

[44] J. P. Williams, M. U. Khan, and N. W. Lem, Physiology, Biochemistry and Molecular Biology of Plant Lipids, Springer Science \& Business Media, Berlin, Germany, 2013.

[45] N. M. H. Eissa, Effect of some plasticulture and fertigation treatments on productivity and fruit quality of straw-berry, Faculty of Agriculture Zagazig University, Ph.D. thesis, 2002.

[46] P. Huang, M. Xun, S. Yue, W. Zhang, W. Fan, and H. Yang, "Effect of rice straw mat and other mulching on apple root architecture and soil environment in root-zone," in Proceedings of the XXX International Horticultural Congress IHC 2018, vol. 1281, pp. 163-170, Istanbul, Turkey, 2018.

[47] G. N. Gupta, "Effects of mulching and fertilizer application on initial development of some tree species," Forest Ecology and Management, vol. 44, no. 2-4, pp. 211-221, 1991.

[48] Y. Gao, Y. Xie, H. Jiang, B. Wu, and J. Niu, "Soil water status and root distribution across the rooting zone in maize with plastic film mulching," Field Crops Research, vol. 156, pp. 40-47, 2014.

[49] C. Bécel, G. Vercambre, and L. Pagès, "Soil penetration resistance, a suitable soil property to account for variations in root elongation and branching," Plant and Soil, vol. 353, no. 12, pp. 169-180, 2012.

[50] R. E. Gough, "Color of plastic mulch affects lateral root development but not root system architecture in pepper," HortScience, vol. 36, no. 1, pp. 66-68, 2001.

[51] H. J. Schenk and R. B. Jackson, "Rooting depths, lateral root spreads and below-ground/above-ground allometries of plants in water-limited ecosystems," Journal of Ecology, vol. 90, no. 3, pp. 480-494, 2002.

[52] R. E. Andrews and E. I. Newman, "Root density and competition for nutrients," Oecologia Plantarum, vol. 5, pp. 319-334, 1970.

[53] S. Yao, I. A. Merwin, and M. G. Brown, "Apple root growth, turnover, and distribution under different orchard groundcover management systems," HortScience, vol. 44, no. 1, pp. $168-175,2009$.

[54] S. M. Benigno, K. W. Dixon, and J. C. Stevens, "Increasing soil water retention with native-sourced mulch improves seedling establishment in postmine Mediterranean sandy soils," Restoration Ecology, vol. 21, no. 5, pp. 617-626, 2013.

[55] H.-C. Fründ and A. Averdiek, "Soil aeration and soil water tension in skidding trails during three years after trafficking," Forest Ecology and Management, vol. 380, pp. 224-231, 2016.

[56] T. S. S. Conlin and R. v. d. Driessche, "Response of soil $\mathrm{CO}_{2}$ and $\mathrm{O}_{2}$ concentrations to forest soil compaction at the longterm soil productivity sites in central British Columbia," Canadian Journal of Soil Science, vol. 80, no. 4, pp. 625-632, 2000.

[57] M. Cambi, Y. Hoshika, B. Mariotti et al., "Compaction by a forest machine affects soil quality and Quercus robur L. seedling performance in an experimental field," Forest Ecology and Management, vol. 384, pp. 406-414, 2017.

[58] A. G. Bengough, B. M. McKenzie, P. D. Hallett, and T. A. Valentine, "Root elongation, water stress, and mechanical impedance: a review of limiting stresses and beneficial root tip traits," Journal of Experimental Botany, vol. 62, no. 1, pp. 59-68, 2011.

[59] J. Lynch, P. Marschner, and Z. Rengel, "Effect of internal and external factors on root growth and development," in Marschner's Mineral Nutrition of Higher Plants, pp. 331-346, Elsevier, Amsterdam, Netherlands, Third edition, 2012.

[60] T. O. Perry, "Tree roots: facts and fallacies," Arnoldia, vol. 49, no. 4, pp. 3-29, 1989.

[61] M. Dobson, "Tree root systems," Arboriculture Research and Information, vol. 130, no. 95, pp. 1-6, 1995.

[62] M. Thidar, D. Gong, X. Mei et al., "Mulching improved soil water, root distribution and yield of maize in the Loess Plateau of Northwest China," Agricultural Water Management, vol. 241, Article ID 106340, 2020.

[63] L. Zhang, Y. Meng, S. Li, and S. Yue, "Film mulching optimizes the early root and shoot development of rain-fed spring maize," Agronomy Journal, vol. 112, no. 1, pp. 309-326, 2020. 
[64] L. Chalker-Scott, "Impact of mulches on landscape plants and the environment-a review," Journal of Environmental Horticulture, vol. 25, no. 4, pp. 239-249, 2007.

[65] S. O. Agele, J. B. Olaore, and F. A. Akinbode, "Effect of some mulch materials on soil physical properties, growth and yield of sunflower (Helianthus Annuus, L)," Advances in Environmental Biology, vol. 4, no. 3, pp. 368-375, 2010.

[66] C. K. Ong and W. Julia, Tree-Crop Interactions, V. B. Dennis, Ed., FSC, Bonn, Germany, 2nd edition, 2015.

[67] A. S. Davis and D. F. Jacobs, "Quantifying root system quality of nursery seedlings and relationship to outplanting performance," New Forests, vol. 30, no. 2-3, pp. 295-311, 2005.

[68] A. Radam, G. M. N. Islam, K. Y. Ng, F. M. Arshad, and E. F. Alias, Impact of Producing Tomatoes under MalaysiaGAP Certification on Farming Practices, Cameron Highlands, pp. 1-24, Food and Agriculture Organization of the United Na-tions (FAO), Rome, Italy, 2015.

[69] P. W. Moody and T. C. Phan, Soil Constraints and Management Package (SCAMP): Guidelines for Sustainable Management of Tropical Upland Soils, Australian Centre for International Agricultural Research (ACIAR), Canberra, Australia, 2008.

[70] L. Eliasson and I. Wästerlund, "Effects of slash reinforcement of strip roads on rutting and soil compaction on a moist finegrained soil," Forest Ecology and Management, vol. 252, no. 1-3, pp. 118-123, 2007.

[71] E. Ampoorter, A. De Schrijver, L. Van Nevel, M. Hermy, and K. Verheyen, "Impact of mechanized harvesting on compaction of sandy and clayey forest soils: results of a metaanalysis," Annals of Forest Science, vol. 69, no. 5, pp. 533-542, 2012.

[72] M. Cambi, G. Certini, F. Neri, and E. Marchi, "The impact of heavy traffic on forest soils: a review," Forest Ecology and Management, vol. 338, pp. 124-138, 2015.

[73] M. Jourgholami, A. Nasirian, and E. Labelle, "Ecological restoration of compacted soil following the application of different leaf litter mulches on the skid trail over a five-year period," Sustainability, vol. 10, no. 7, p. 2148, 2018.

[74] M. Jourgholami, K. Fathi, and E. R. Labelle, "Effects of litter and straw mulch amendments on compacted soil properties and Caucasian alder (Alnus subcordata) growth," New Forests, vol. 51, no. 2, pp. 349-365, 2020.

[75] L. A. Billeaud and J. M. Zajicek, "Influence of mulches on weed control, soil $\mathrm{pH}$, soil nitrogen content, and growth of Ligustrum japonicum," Journal of Environmental Horticulture, vol. 7, no. 4, pp. 155-157, 1989.

[76] J. K. Iiles, "Effect of organic and mineral mulches in soil properties and growth of fairview flame red maple trees," Journal of Arboriculture, vol. 25, no. 3, pp. 163-167, 1999.

[77] S. X. Li, Z. H. Wang, S. Q. Li, Y. J. Gao, and X. H. Tian, "Effect of plastic sheet mulch, wheat straw mulch, and maize growth on water loss by evaporation in dryland areas of China," Agricultural Water Management, vol. 116, pp. 39-49, 2013.

[78] A. Sinkevičienè, D. Jodaugienè, R. Pupalienè, and M. Urboniene, "The influence of organic mulches on soil proper-ties and crop yield," Agronomy Research, vol. 7, no. 1, pp. 485-491, 2009.

[79] X. Han, Y. L. Li, L. F. Wang, S. L. Liu, and J. G. Zhang, "Effect of tree-row mulching on soil characteristics as well as growth and development of pear trees," Acta Horticulturae, vol. 1094, pp. 299-306, 2014.

[80] C. K. Thankamani, K. Kandiannan, S. Hamza, and K. V. Saji, "Effect of mulches on weed suppression and yield of ginger
(Zingiber officinale Roscoe)," Scientia Horticulturae, vol. 207, pp. 125-130, 2016.

[81] S. K. Ogundare, I. J. Babatunde, and O. O. Etukudo, "Response of tomato variety (Roma F) yield to different mulch materials and staking in Kabba, Kogi State, Nigeria," Journal of Agricultural Studies, vol. 3, no. 2, pp. 61-70, 2015.

[82] S. Hosseini Bai, T. J. Blumfield, and F. Reverchon, "The impact of mulch type on soil organic carbon and nitrogen pools in a sloping site," Biology and Fertility of Soils, vol. 50, no. 1, pp. 37-44, 2014.

[83] T. Adak, "Soil organic carbon, dehydrogenase activity, nutrient availability and leaf nutrient content as affected by organic and inorganic source of nutrient in mango orchard soil," Journal of Soil Science and Plant Nutrition, vol. 14, pp. 394-406, 2014.

[84] Y. P. Wang, X. G. Li, T. Fu et al., "Multi-site assessment of the effects of plastic-film mulch on the soil organic carbon balance in semiarid areas of China," Agricultural and Forest Meteorology, vol. 228-229, pp. 42-51, 2016.

[85] A. R. Khan, S. S. Singh, P. S. B. Anand, P. Nanda, and D. Chandra, "Effect of organic mulching on physi-cochemical properties of soil," Abdus Salam International Centre for Theoretical Physics, Trieste, Italy, No. IC/IR-2002/ 15, 2002.

[86] K. Fite, E. Thomas Smiley, J. McIntyre, and C. E. Wells, "Evaluation of a soil decompaction and amendment pro-cess for urban trees," Arboriculture \& Urban Forestry, vol. 37, no. 6 , p. 293, 2011.

[87] A. Muttaleb, The Effect of Three Different Mulches on Weed Presence, Soil Characteristics, and Zinnia Growth, Murray State University, Murray, KY, USA, 2018.

[88] B. D. McIntyre, P. R. Speijer, S. J. Riha, and F. Kizito, "Effects of mulching on biomass, nutrients, and soil water in banana inoculated with nematodes," Agronomy Journal, vol. 92, no. 6, pp. 1081-1085, 2000.

[89] G. S. Saroa and R. Lal, "Mulching effects on phosphorus and sulfur concentrations in a Miamian soil in central Ohio, USA," Land Degradation \& Development, vol. 15, no. 4, pp. 351-365, 2004.

[90] M. A. Haque, M. Jahiruddin, and D. Clarke, "Effect of plastic mulch on crop yield and land degradation in south coastal saline soils of Bangladesh," International Soil and Water Conservation Research, vol. 6, no. 4, pp. 317-324, 2018. 